\title{
………

\section{Kajian Keberadaan Ojek Sebagai Angkutan Umum Paratransit Di Kota Semarang (Studi Kasus: Koridor Jalan Kesatrian, Jalan Ngesrep Timur V Dan Jalan Karangrejo Raya)}

\section{Ratna Pratiwi', Ragil Haryanto ${ }^{2}$}

Diterima : Juli 2015

Disetujui : 7 September 2015

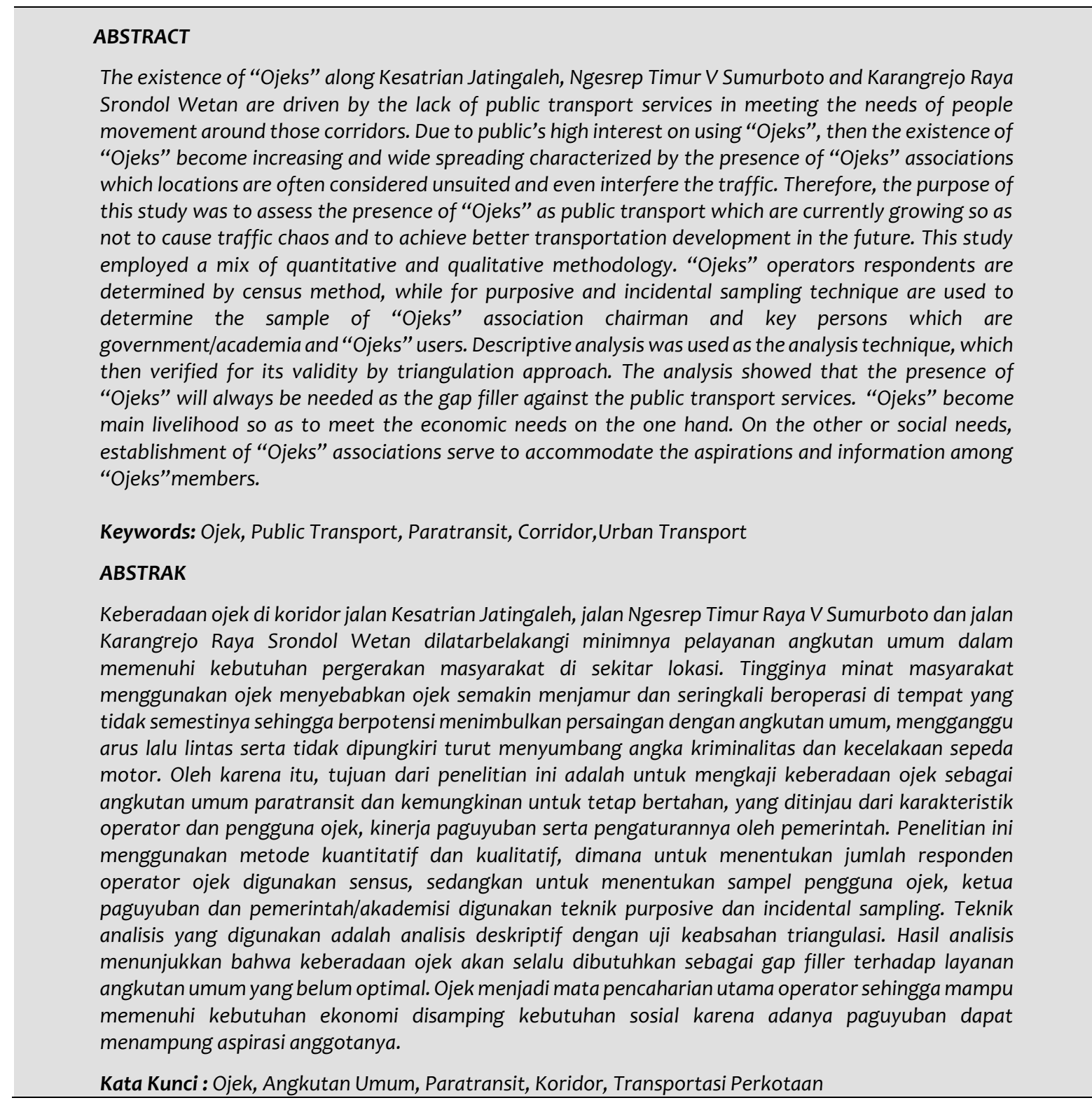

\footnotetext{
1 Pusat Data Dan Informasi Sekretariat JenderalKementerian Perhubungan

Kontak penulis: pratiwi_ratna@yahoo.com

2 Dosen Magister Pembangunan Wilayahdan Kota, Undip Semarang, Jawa Tengah
} 


\section{PENDAHULUAN}

Di kota Semarang, tepatnya di koridor jalan Kesatrian Jatingaleh, jalan Ngesrep Timur V dan jalan Karangrejo Raya Banyumanik, ojek menjadi angkutan umum yang mudah ditemukan. Ketiga koridor tersebut merupakan lokasi dengan mobilitas penduduk yang sangat tinggi namun minim pelayanan angkutan umum. Hal tersebut yang memunculkan permasalahan yaitu masyarakat yang ada di sekitar wilayah tersebut kesulitan untuk menjangkau wilayah yang masuk lebih jauh lagi, misalnya koridor jalan Kesatrian yang sama sekali tidak dilalui angkutan umum. Kemudian koridor jalan Ngesrep Timur $\mathrm{V}$ merupakan akses menuju kawasan pendidikan dengan mobilitas tinggi para mahasiswa Undip Semarang. Selain itu banyaknya pemukiman dan kost yang tersebar sampai ke wilayah pinggiran sulit dijangkau masyarakat karena tidak dilalui trayek angkutan umum. Koridor jalan Karangrejo Raya Banyumanik yang berhadapan langsung dengan sub terminal Banyumanik khususnya ke arah permukiman padat penduduk yaitu Perumnas Banyumanik juga tidak dilayani oleh angkutan umum.

Ojek yang dalam operasinya menggunakan sepeda motor, merupakan alat transportasi paling rentan terhadap keselamatan. Fakta menyebutkan bahwa salah satu penyebab kematian terbesar di Indonesia adalah akibat kecelakaan lalu lintas yang melibatkan kendaraan sepeda motor. Desain sepeda motor memerlukan keseimbangan saat berkendara dan kondisi tempat duduk tanpa penutup sehingga tidak terlindungi dari gangguan cuaca atau mengundang kriminalitas di jalan raya. Berdasarkan hasil wawancara dengan ketua paguyuban di jalan Ngesrep Timur V dan Karangrejo Raya, juga membenarkan pernah terjadi tindakan penipuan namun justru dilakukan oleh penumpang ojek sehingga mengakibatkan sepeda motor tukang ojek raib dibawa kabur penumpang. Hal tersebut menunjukkan bahwa keberadaan ojek secara tidak langsung turut menyumbang angka kecelakaan lalu lintas dan kriminalitas.

Tingginya minat masyarakat dalam memanfaatkan keberadaan ojek justru membuat jumlah operator/tukang ojek semakin meningkat dan wilayah beroperasinya pun semakin meluas. Hal tersebut mendorong para tukang ojek untuk membentuk sebuah paguyuban dan mangkal di tempat yang tidak seharusnya seperti di sudut perempatan atau tikungan jalan raya, kemudian menggunakan bahu jalan dan bahkan trotoar yang diperuntukkan bagi pejalan kaki. Hal ini berpotensi menimbulkan masalah yaitu kesemrawutan seperti kemacetan lalu lintas yang pada akhirnya mengakibatkan arus transportasi menjadi tidak tertib dan lancar. Seperti yang diungkapkan oleh kepala Kelurahan Sumurboto bahwa di ujung jalan Ngesrep Timur V sering terjadi kesemrawutan karena mangkalnya ojek Patung Diponegoro pada bahu jalan dan trotoar.

Permasalahan lain adalah dari sisi regulasi dimana ojek hanya sebagai angkutan informal/paratransit yang belum diatur dalam peraturan perundangan. UU No. 22/2009 tentang Lalu Lintas Angkutan Jalan bab X bagian ketiga menyebutkan bahwa penyelenggaraan angkutan orang dengan kendaraan bermotor umum adalah menggunakan mobil penumpang umum dan mobil bus umum. Selanjutnya pasal 151 menyebutkan bahwa pelayanan angkutan orang dengan kendaraan bermotor umum tidak dalam trayek sebagaimana dimaksud dalam Pasal 140 huruf $b$ terdiri atas: (a) angkutan orang dengan menggunakan taksi; (b) angkutan orang dengan tujuan tertentu; (c) angkutan orang untuk keperluan pariwisata; dan (d) angkutan orang di kawasan tertentu. Tidak ada penjelasan yang menyebutkan bahwa salah satu angkutan orang yang dimaksud termasuk ojek, padahal ojek merupakan kendaraan bermotor umum untuk mengangkut orang dan tidak mempunyai trayek. Namun menurut UU no. 55/2012 tentang Kendaraan, ojek memang tidak memenuhi syarat sebagai kendaraan bermotor umum. 
Namun permasalahan utama dari suatu kota khususnya kota Semarang yang diangkat pada penelitian ini adalah adanya kekosongan pelayanan transportasi yaitu tidak adanya angkutan umum di koridor jalan Kesatrian dan tidak optimalnya trayek angkutan umum yang beroperasi pada koridor jalan Ngesrep Timur V dan jalan Karangrejo Raya. Hal ini terkait juga dengan perencanaan kota yang belum terintegrasi dengan perencaaan transportasi, misalnya tentang penataan guna lahan (land use) kurang memperhatikan jangkauan pelayanan transportasi seperti door to door service dan sebagainya. Oleh karena itu berdasarkan rumusan permasalahan diatas, research questions dalam penelitian ini adalah: Bagaimanakah keberadaan dan kebertahanan ojek sebagai angkutan umum paratransit pada koridor jalan Kesatrian, jalan Ngesrep Timur V dan jalan Karangrejo Raya kota Semarang, bila ditinjau dari sisi operator dan pengguna ojek, sisi kelembagaan paguyuban ojek serta sisi pengaturannya menurut pandangan pemerintah? Rekomendasi apakah yang dapat diberikan dalam menyikapi keberadaan ojek tersebut?

\section{METODOLOGI PENELITIAN}

Penelitian ini menggunakan pendekatan campuran yaitu gabungan antara metode kuantitatif dan kualitatif dengan format deskriptif, dimana dipilih metode kuantitatif dengan jenis survei dan metode kualitatif dengan jenis studi kasus. Metode kuantitatif survei digunakan untuk menggambarkan karakteristik operasional para tukang ojek yang selanjutnya diperoleh data berupa angka yang disajikan dalam bentuk diagram atau tabel. Sedangkan metode kualitatif studi kasus digunakan untuk mengetahui pendapat pengguna ojek, kinerja paguyuban/pangkalan ojek serta untuk mengetahui bagaimana pandangan pemerintah dan akademisi mengenai pengaturan yang tepat dalam menyikapi keberadaan ojek. Pengumpulan data kuantitatif menggunakan angket/kuesioner, sedangkan untuk data kualitatif melalui wawancara, observasi dan dokumenter. Untuk jumlah responden operator ojek ditentukan dengan metode sensus yaitu sebanyak 85 orang, sedangkan untuk menentukan sampel dari pengguna ojek, ketua paguyuban ojek dan keyperson/experts yaitu pemerintah dan akademisi menggunakan teknik purposive dan incidental sampling, dimana diperoleh jumlah keyperson sebanyak 15 orang Teknik analisis yang digunakan untuk data kuantitatif adalah analisis statistik deskriptif, sedangkan untuk data kualitatif menggunakan proses reduksi, penyajian data dan penarikan kesimpulan, yang selanjutnya diuji keabsahannya dengan pendekatan triangulasi.

\section{GAMBARAN UMUM LOKASI PENELITIAN}

Lokasi penelitian ini berada di kota Semarang dan secara mikro berada pada 3 (tiga) lokasi pangkalan ojek, yaitu ojek POAK (Paguyuban Ojek Anak Kesatrian) di koridor jalan Kesatrian, ojek Patung Diponegoro di jalan Ngesrep Timur V, dan ojek Bangjo (Abang ljo) di jalan Karangrejo Raya. 


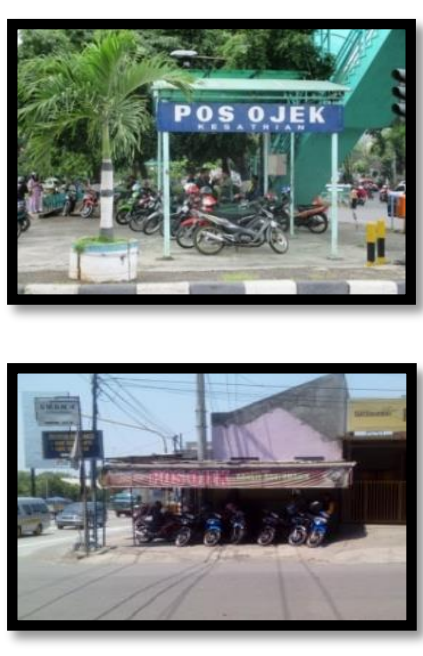

Sumber: Penyusun, 2015
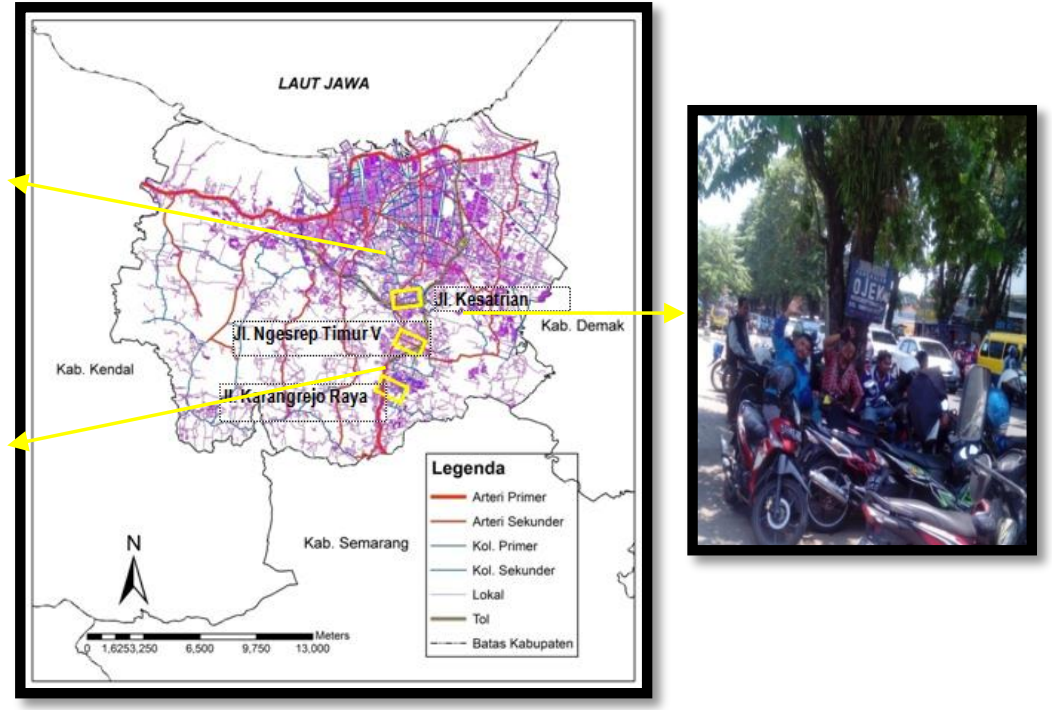

\section{GAMBAR 1. PETA LOKASI PENELITIAN}

Koridor jalan Kesatrian di kelurahan Jatingaleh Kecamata Candisari yang merupakan jalan kolektor sekunder, memiliki panjang kurang lebih 1,2 km dengan lebar bervariasi sekitar 8-12 m. Di ujung koridor jalan Kesatrian, tepatnya di bawah jembatan penyeberangan orang Jatingaleh dekat pintu masuk tol Jatingaleh terdapat pangkalan ojek POAK (Paguyuban Ojek Anak Kesatrian). Paguyuban ini memiliki sekretariat di Jalan Kesatrian Asr. KBPT RT 03/07 B-24 Jatingaleh Semarang. Pangkalan ojek ini menempati lahan damija seluas $12 \times 6$ meter persegi pada ruas Jl. Teuku Umar yang merupakan area Taman Sekuter sebagai Ruang Terbuka Hijau (RTH). Pangkalan ojek ini sudah ada sejak tahun 1978 dengan jumlah anggota sebanyak 25 orang dengan waktu operasi selama 24 jam tanpa pembagian jam kerja (shift).

Koridor jalan Ngesrep Timur V di kelurahan Sumurboto kecamatan Banyumanik yang merupakan jalan akses utama menuju dan dari kawasan kampus Universitas Diponegoro Tembalang, memiliki panjang kurang lebih 1,5 km dengan lebar keseluruhan bervariasi antara 14-19 m. Di ujung koridor jalan Ngesrep Timur $V$ tepatnya di dekat patung Pangeran Diponegoro kampus Undip Semarang terdapat pangkalan ojek Patung Diponegoro. Paguyuban ojek ini telah ada sejak tahun 1980 dan memiliki kantor sekretariat di Jalan Ngesrep Timur V Gang Melati, Sumurboto, Semarang. Pangkalan ojek ini masih menempati bahu jalan dan trotoar pada sisi utara Jalan Ngesrep Timur $\mathrm{V}$, di bawah sebuah pohon yang cukup rindang untuk berteduh. Jumlah anggota aktif sebanyak 25 orang dengan waktu operasi selama 24 jam tanpa pembagian jam kerja (shift).

Koridor jalan Karangrejo Raya di kelurahan Srondol Wetan kecamatan Banyumanik merupakan jalan kolektor sekunder dengan panjang kurang lebih 1,5 km dengan lebar keseluruhan bervariasi sekitar 10-12 m. Di ujung koridor jalan ini terdapat pangkalan ojek Bangjo (abang ijo) karena letak pangkalan ojek ini tepat berada di bawah traffic light yang berada di depan/seberang terminal Banyumanik Semarang. Pangkalan ojek yang telah ada sejak tahun 1978 ini memiliki kantor sekretariat yang beralamat di Jalan Bendo Waringin Putih, Srondol Wetan, Semarang, dan saat ini masih menempati trotoar pada sisi utara Jalan Karangrejo Raya, bersebelahan langsung 
dengan sebuah toko dan sebuah restoran di sudut jalan. Jumlah anggota aktif 35 orang dengan waktu operasi 24 jam yang terbagi menjadi 2 (dua) shift, yaitu 22 orang dari pukul $07.00-19.00$ dan 13 orang dari pukul $19.00-07.00$.

\section{KAJIAN TEORI}

Angkutan umum penumpang menurut Warpani (1990) adalah angkutan penumpang yang menggunakan kendaraan umum yang dilakukan dengan sistem sewa atau bayar. Termasuk dalam pengertian angkutan umum penumpang adalah angkutan kota (bus, minibus, dsb), kereta api, angkutan air, dan angkutan udara. Tujuan utama keberadaan angkutan umum penumpang adalah menyelenggarakan pelayanan angkutan yang baik dan layak bagi masyarakat. Ukuran pelayanan angkutan umum yang baik adalah pelayanan yang aman, cepat, murah, dan nyaman.

Ojek merupakan salah satu angkutan umum paratransit yang beroperasi di Indonesia. Istilah "paratransit" dapat diartikan sebagai "informal", "intermediate" atau "unconventional" (Iles, 2005). Jadi angkutan paratransit dapat disebut juga sebagai angkutan informal. Istilah paratransit berlaku untuk kendaraan penumpang kecil yang beroperasi secara tak resmi dengan menarik ongkos, dan melayani sejumlah tempat sebagai alternatif pelayanan angkutan bus biasa. Adapun definisi ojek adalah sepeda atau sepeda motor yang diojekkan (ditambangkan) dengan cara memboncengkan penumpang atau penyewanya untuk memperoleh (tambahan) nafkah (Tim Penyusun Kamus Pusat Pembinaan Pengembangan Bahasa, dalam Handayani, 2009).

Undang-Undang Republik Indonesia Nomor 22 Tahun 2009 Tentang Lalu Lintas dan Angkutan Jalan pada pasal 1 ayat (10) menyebutkan bahwa: Kendaraan Bermotor Umum adalah setiap Kendaraan yang digunakan untuk angkutan barang dan/atau orang dengan dipungut bayaran. Menurut Saputra (2012), pada pasal 137 ayat (2) beserta Peraturan Pemerintah No. 41 tahun 1993 pasal 2 jo Peraturan Pemerintah No. 74 tahun 2014 pasal 4 tentang Angkutan Jalan menyebutkan bahwa pengangkutan orang dilakukan dengan menggunakan sepeda motor, mobil penumpang, atau bus. Dalam Surat Menteri Perhubungan Nomor Aj.206/I/4/Phb-2003 perihal kendaraan bermotor roda dua sebagai angkutan umum, menyebutkan untuk keberadaan roda dua yang sekarang ini marak digunakan sebagai angkutan umum harus benar-benar dibatasi agar tidak menganggu angkutan umum serta ketertiban lalu lintas. Beberapa referensi diatas adalah sebagian kecil petunjuk yang menguatkan legalitas ojek itu sendiri walaupun nomenklatur penyebutan kata "ojek" tidak tercantum secara gamblang dalam undang-undang. Secara nomenklatur penyebutan kata "sepeda motor" belum memperjelas apakah angkutan orang yang dimaksud adalah ojek.

Era (2014) manyatakan bahwa kekosongan aturan mengenai ojek di dalam undang-undang membuat solusi mengenai permasalahan-permasalahan ojek adalah dengan mengeluarkan aturan yang tingkatnya di bawah Undang-Undang, seperti Peraturan Daerah berikut ini yang dibuat untuk melegalkan keberadaan ojek:

a. Peraturan Daerah Kota Palopo Sulawesi Selatan Nomor 04 Tahun 2004 Tentang Retribusi Izin Sepeda Motor (Ojek) Sebagai Angkutan Alternatif Masyarakat.

b. Peraturan Daerah Kabupaten Dompu Nusa Tenggara Barat Nomor 7 Tahun 2004 Tentang Petunjuk Pelaksanan Izin Usaha Angkutan Penumpang Umum Dengan Kendaraan Bermotor Roda Dua/Ojek. 
c. Peraturan Daerah Kabupaten Majene Sulawesi Barat Nomor 12 Tahun 2004 Tentang Usaha Angkutan Dan Retribusi Izin Usaha Angkutan Khusus (ojek).

Peranan pemerintah sebagai regulator sangat diperlukan dalam mengatur, membina dan mengawasi penyelenggaraan pelayanan transportasi. Pemerintah mengharapkan kegiatan pelayanan transportasi berlangsung secara lancar, tertib dan teratur, berkapasitas cukup, tidak terjadi dampak negatif yang besar misalnya kemacetan, kecelakaan atau pemogokan. Dalam beberapa kebijakan pemerintah yang sangat penting, suatu survei transportasi salah satunya harus menguji sifat sistem pengaturan (Adisasmita, 2011).

Analisis kelembagaan merupakan kegiatan mempelajari kelembagaan dengan mendalami berbagai hal yang terkait dalam kelembagaan, misalnya mengetahui historik perkembangannya, mengukur kapasitasnya, memahami perselisihan dan konflik, mengidentifikasi kepemimpinannya, manajemennya, permodalannya, dan lain-lain. Analisis kelembagaan mempelajari bagaimana lembaga yakni struktur dan mekanisme dari keteraturan sosial dan kerjasama membentuk perilaku dua sampai lebih orang. Disini juga dipelajari bagaimana individual dan kelompok-kelompok membentuk lembaga, bagaimana lembaga berjalan, dan apa efek dari lembaga pada masyarakat (Syahyuti, 2010). Kajian kelembagaan ini digunakan sebagai masukan untuk melakukan analisis terhadap paguyuban ojek sebagai salah satu contoh kelembagaan non-formal yang ada di masyarakat.

\section{ANALISIS KEBERADAAN OJEK SEBAGAI ANGKUTAN UMUM PARATRANSIT DI KOTA SEMARANG}

\section{Analisis Karakteristik Operasional Ojek}

Keberadaan ojek di tiga lokasi penelitian ini tidak menunjukkan banyak perbedaan pada karakteristik operasionalnya. Banyaknya usia produktif yang menjadikan ojek sebagai mata pencaharian menunjukkan bahwa menjadi operator ojek dapat menjadi peluang yang menjanjikan untuk memperbaiki kesejahteraan ekonomi keluarga. Sedangkan sebagian dari operator ojek dengan usia lebih dari 50 tahun menunjukkan bahwa profesi sebagai operator ojek tidak memerlukan tenaga yang kuat, selain itu operator ojek yang rata-rata hanya lulusan SLTP dan SLTA menunjukkan bahwa profesi sebagai operator ojek juga tidak memerlukan jenjang pendidikan tinggi. Secara kumulatif di tiga lokasi penelitian mayoritas operator ojek menjadikan profesi operator ojek sebagai pekerjaan tetap. Sedangkan operator ojek lainnya hanya menjadikan profesi operator ojek sebagai pekerjaan sampingan karena sudah mempunyai pekerjaan tetap sebagai buruh dan pedagang, dan ada juga sebagai satpam bahkan PNS.

Rata-rata operator ojek beroperasi dalam waktu yang tidak tentu dan sebagian lainnya ada yang beroperasi rutin sebanyak 5 hari sampai 7 hari selama seminggu, sedangkan dalam sehari mayoritas tukang ojek beroperasi selama 8 jam, selebihnya tidak menentu. Hampir separuh dari seluruh tukang ojek yang disensus hanya mengangkut kurang dari 10 orang penumpang per hari dengan tarif minimal antara Rp 4.000,- sampai Rp 5.000,-. Sehingga penghasilan yang diperolah berkisar antara 1-1,5 juta rupiah tiap bulan. Hal ini mayoritas terjadi di pangkalan ojek Patung Diponegoro karena adanya moda transportasi lain yaitu Mobil Penumpang Umum (MPU) R.8.e. Disusul kemudian di pangkalan ojek BANGJO yang dilalui oleh MPU C.10.

Sebagian besar para penumpang ojek adalah dari kalangan umum dan pelajar. Kalangan umum yang dimaksud adalah ibu rumah tangga, guru, pegawai pedagang atau buruh. Sedangkan kalangan pelajar adalah anak sekolah atau mahasiswa. Penumpang dari kalangan mahasiswa 
banyak terdapat di pangkalan ojek Patung Diponegoro karena merupakan kawasan pendidikan yaitu Universitas Diponegoro. Beberapa operator ojek memiliki penumpang tetap yang menjadi langganan. Jumlah pelanggan ojek tersebut antara satu operator berbeda dengan operator ojek lainnya, yaitu berkisar 1-4 orang dengan mayoritas tujuan antar-jemput sekolah, pergi dari dan ke rumah, serta tergantung permintaaan dengan tujuan kemana saja.

Jarak terdekat yang ditempuh adalah antara $500 \mathrm{~m}$ sampai $2 \mathrm{~km}$ dengan tarif minimal antara $\mathrm{Rp}$ 4.000,- sampai Rp 5.000,-. Sedangkan jarak terjauh yang ditempuh dapat dibedakan menjadi dua yaitu tujuan di dalam kota Semarang dengan tarif antara Rp 15.000,- sampai Rp 50.000,-.dan di luar kota Semarang tanpa batas jarak, dengan tarif tertinggi misalnya ke kota Wonosobo sebesar Rp 300.000,-. Namun sebagian operator ojek dapat memberikan tarif yang lebih murah apabila mengenal siapa penumpangnya, baik itu tetangga rumah maupun yang sudah menjadi pelanggan tetap dan sering menggunakan jasa ojek tersebut.

Berikut ini disajikan tabel perbandingan keberadaan ojek berdasarkan jawaban mayoritas/terbanyak terhadap karakteristik operasionalnya:

TABEL 1

PERBANDINGAN KARAKTERISTIK OPERASIONAL OJEK

\begin{tabular}{|c|c|c|c|}
\hline Karakteristik & POAK & Patung Diponegoro & BANGJO \\
\hline Usia & $40-50$ th & $>50$ th & $>50$ th \\
\hline Pendidikan & SLTA & SLTP & SLTA \\
\hline Status profesi ojek & tetap & sampingan & tetap \\
\hline Pendapatan rata-rata & $1-1,5$ juta & $<1$ juta & $1-1,5$ juta \\
\hline Lama kerja & $1-5$ th; $11-20$ th & $11-20$ th & $11-20$ th \\
\hline Waktu operasi dalam seminggu & 7 hari & Tidak tentu & Tidak tentu \\
\hline Waktu operasi dalam sehari & $>8$ jam & Tidak tentu & $>8$ jam \\
\hline $\begin{array}{l}\text { Daya angkut penumpang } \\
\text { perhari }\end{array}$ & $>15$ orang & $<10$ orang & $11-15$ orang \\
\hline Ada tidaknya pelanggan & Tidak ada & Ada & Tidak ada \\
\hline
\end{tabular}

Sumber: Hasil Analisis, 2015

Hasil sintesa ini diantaranya senada dengan Handayani, Mochtar dan Soemitro (2009) dalam penelitian Alat Transportasi Informal Ojek Sepeda Motor di Kota Surakarta, yang menyampaikan hasil penelitian bahwa pekerjaan sebagai operator ojek adalah salah satu bentuk pekerjaan informal yang dapat membantu masyarakat dalam mencukupi kebutuhan hidup, karena mayoritas operator ojek menjadikan profesi operator ojek sebagai pekerjaan tetap dan hanya beberapa yang mempunyai pekerjaan sampingan. Mengenai pekerjaan sampingan ini juga diteliti oleh Fasakin (2001) sebagai karakteristik dari aspek sosial ekonomi operator ojek selain jumlah hari kerja, jumlah penumpang, kriteria jarak tempuh yang mempengaruhi keuntungan harian taksi sepeda motor (Okada) di Akure, Nigeria.

\section{Analisis Pendapat Pengguna Ojek Terhadap Keberadaan Ojek}

Mayoritas para pengguna ojek telah menggunakan jasa ojek selama kurang lebih 4-10 tahun atau bertahun-tahun sejak pangkalan ojek mulai ada di lokasi tersebut. Para pengguna ojek pada umumnya menggunakan ojek untuk menempuh jarak dekat seperti pulang ke rumah, ke kantor atau ke sekolah, para penumpang menggunakan ojek hanya sebagai feeder untuk melanjutkan perjalanan setelah naik angkutan umum penumpang (AUP). Untuk tujuan ke pasar tradisional 
pada umumnya angkutan ojek berperan sebagai substitute angkutan umum yaitu menggunakan ojek dari mulai keluar rumah langsung ke tujuan tanpa perlu menggunakan AUP terlebih dahulu. Untuk tujuan jarak dekat antara 1-2 km tarif ojek masih dianggap murah, sedangkan untuk jarak jauh (lebih dari $2 \mathrm{~km}$ ) tarif ojek ditentukan dengan kesepakatan bersama dan masih dianggap cukup terjangkau mengingat efektifitas waktu yang diperoleh. Para penumpang lebih memilih ojek dari pada angkutan Mobil Penumpang Umum (MPU) yang beroperasi, karena dapat menghindari angkot yang sering ngetem, lalu lebih cepat dan fleksibel dengan tujuan kemana pun serta langsung sampai tujuan. Sedangkan khusus para pengguna ojek POAK di Kesatrian, alasan memilih ojek adalah karena tidak ada alternatif angkutan umum lainnya.

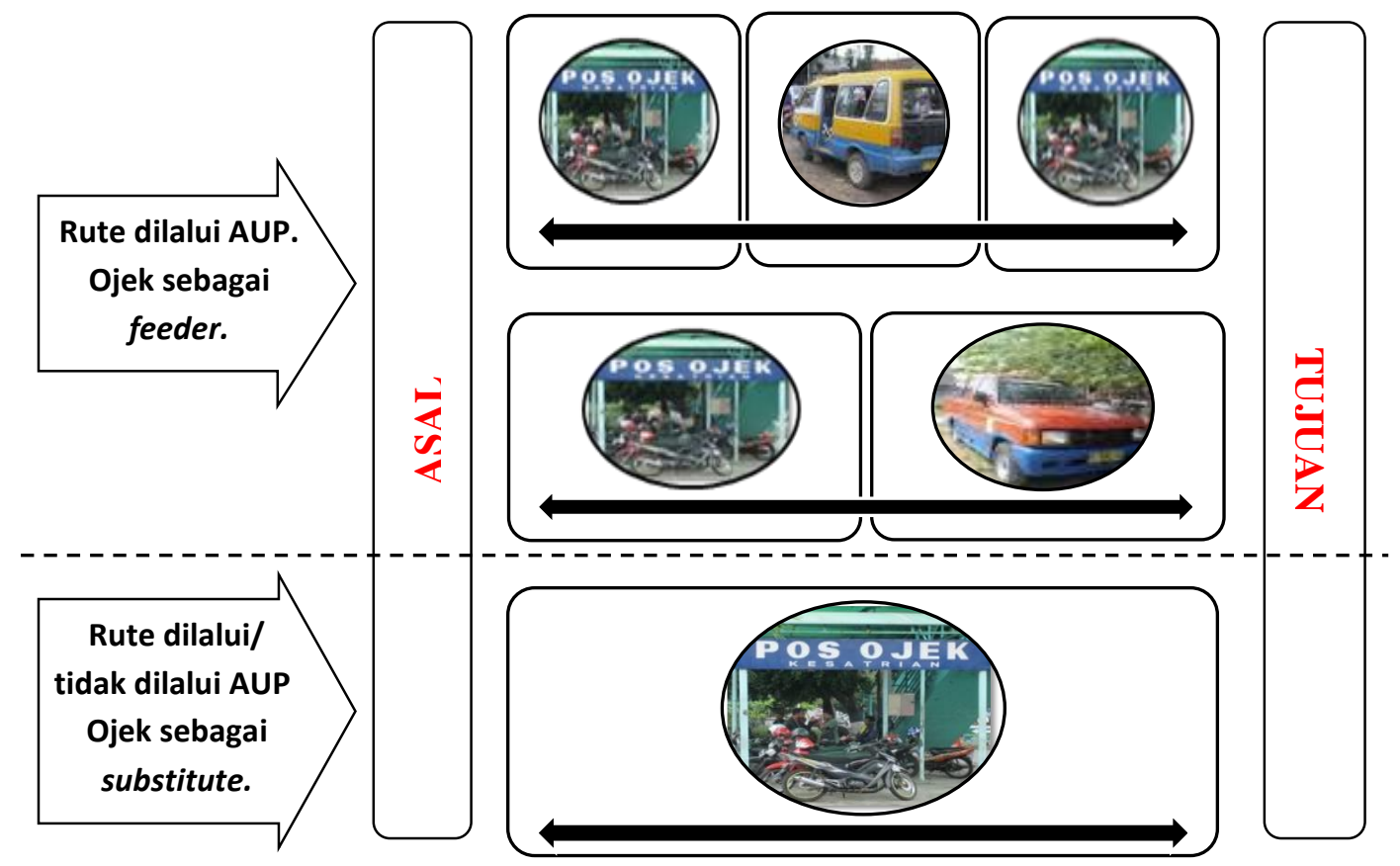

Sumber: Hasil Analisis, 2015

GAMBAR 2. SKEMA KEBUTUHAN PENGGUNA OJEK

Mayoritas pengguna ojek menyatakan bahwa saat menggunakan ojek selalu merasa aman dan nyaman karena sudah saling mengenal dengan beberapa operator ojek. Selain itu cepat atau tidaknya operator dalam mengendarai ojek dapat disesuaikan dengan permintaan penumpang. Secara umum keberadaan ojek di lokasi penelitian tidak mengganggu lalu-lintas dan tidak menyebabkan kemacetan. Lebih lanjut para penumpang ojek menjelaskan bahwa lokasi pangkalan sudah pada tempatnya. Sehingga utuk kedepannya seharusnya ojek memang perlu untuk diresmikan atau dilformalkan agar lebih tertib dan teratur. Selain itu penggun ojek setuju bila para operator diberikan identitas seperti helm dan seragam, tapi tidak setuju bila tarif dan rute juga ditentukan.

Hasil sintesa ini diantaranya senada dengan Edi (2005) dalam penelitian Karakteristik Pengoperasian Angkutan Ojek Sebagai Sarana Angkutan Dalam Melayani Permintaan Masyarakat di Kota Gubug, yang menyampaikan bahwa angkutan ojek sangat membantu penduduk dalam mendukung pergerakan lokal, misalnya ke pasar tradisional, sekolah dan kantor. Hasil ini diperkuat oleh Joewono (2005) bahwa pengguna moda paratransit di kota Bandung sebagian besar menempuh perjalanan untuk jarak kurang dari $5 \mathrm{~km}$. Selanjutnya 
disampaikan pula oleh Bahar, Tamin, Kusbiantoro dan Frazila (2011) dalam penelitian Potensi Penggunaan Angkutan Informal di Kota Bandung, menyampaikan hasil bahwa lebih dari $70 \%$ pengguna ojek sepeda motor di Kota Bandung saat ini cenderung mempertahankan ojek sepeda motor sebagai angkutan penumpang alternatif, yang berperan sebagai feeder, gap filler, dan substitusi.

\section{Analisis Kinerja Paguyuban Ojek}

Perkembangan ojek selama 10 tahun terakhir relatif baik dengan ditandai adanya paguyuban yang terorganisir, dan tempat yg semakin layak sehingga mempunyai prospek supply pergerakan yang menjajikan dan berpeluang sebagai suatu bisnis untuk tujuan pemenuhan kebutuhan ekonomi. Ketiga paguyuban ojek tersebut meskipun secara karakteristik waktu operasi (shift) berbeda namun ketiganya telah mampu menempatkan peran dan fungsi kelembagaan secara tepat sehingga tujuan yang ditetapkan dapat tercapai dengan baik.

Paguyuban ojek mempunyai peraturan internal baik tertulis maupun tidak tertulis yang harus diterapkan dan dilaksanakan bersama para anggota paguyuban ojek ini, adalah salah satu sistem dalam mengatur dan mewujudkan iklim kerja yang kondusif dan kelancaran dalam bekerja. Salah satu aturan yang disepakati bersama untuk menciptakan iklim kerja yang nyaman adalah dengan mengadakan pertemuan rutin antar anggota. Paguyuban ojek berhubungan erat dengan upaya peningkatan iklim kerja yang berdampak positif terhadap tingkat kesejahteraan ekonomi dan hubungan sosial para anggotanya.

Penyediaan sarana dan prasarana secara campuran dilakukan oleh anggota kelembagaan dengan swadaya membayar iuran rutin, dan bekerja sama dengan pihak di luar kelembagaan. Hingga saat ini bantuan sarana prasarana belum pernah diperoleh dari pemerintah namun diperoleh dari pihak swasta/sponsor atau partai politik dengan bentuk bantuan misalnya spanduk nama pangkalan dan kaos. Sedangkan sarana yang ada di pangkalan ojek seperti: kanopi, meja, kursi, papan antrian diperoleh dengan swadaya. Prasarana adalah area yang digunakan sebagai pangkalan yaitu RTH, trotoar atau bahu jalan. Adapun kelengkapan lain yang harus dimliki selain surat-surat kendaraan adalah Kartu Tanda Anggota paguyuban yang diperoleh dengan swadaya (paguyuban ojek POAK) dan dari Polsek (paguyuban Patung Diponegoro dan BANGJO).

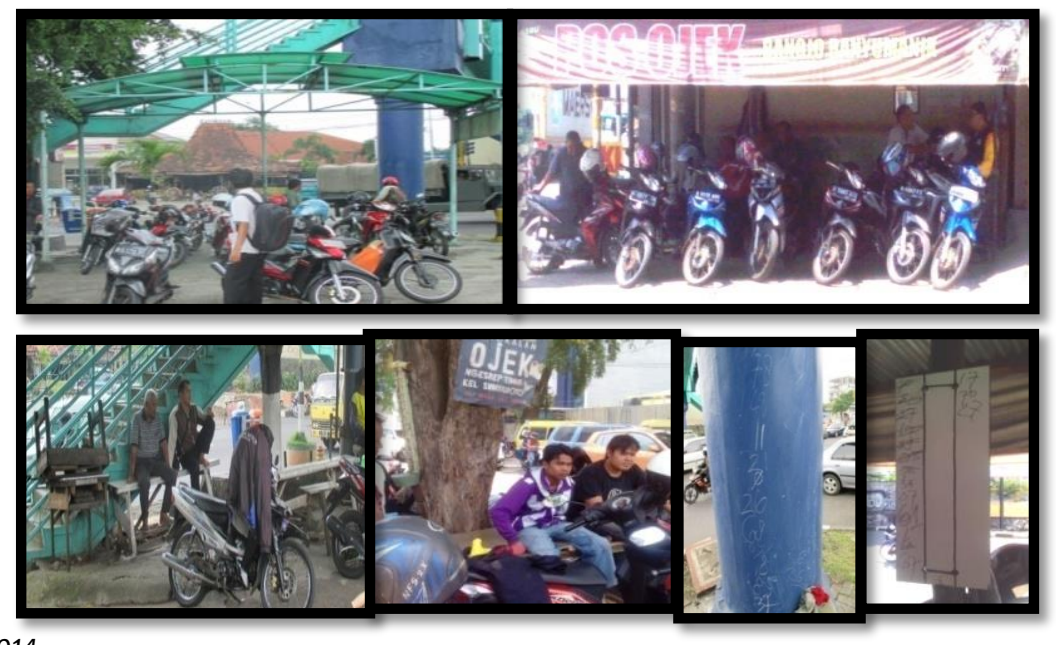

Sumber: Penyusun, 2014

\section{GAMBAR 3.}

SARANA DAN PRASARANA DI PANGKALAN OJEK 
Berikut ini disajikan tabel perbandingan keberadaan ojek berdasarkan jawaban mayoritas/terbanyak terhadap karakteristik operasionalnya:

TABEL 2

PERBANDINGAN KELEMBAGAAN PAGUYUBAN OJEK

\begin{tabular}{|c|c|c|c|}
\hline Karakteristik & POAK & Patung Diponegoro & BANGJO \\
\hline Tahun didirikan & 1978 & 1980 & 1978 \\
\hline Jumlah anggota & 25 orang & 25 orang & 35 orang \\
\hline Asal Anggota & $\begin{array}{l}\text { Sekitar wilayah } \\
\text { Kesatrian }\end{array}$ & $\begin{array}{l}\text { Sekitar wilayah } \\
\text { Ngesrep dan Luar } \\
\text { kota }\end{array}$ & $\begin{array}{c}\text { Sekitar wilayah } \\
\text { Srondol dan Luar } \\
\text { kota }\end{array}$ \\
\hline Sekretariat & Ada & Tidak ada & Tidak ada \\
\hline Lokasi pangkalan & Damija/Taman Sekuter & Bahu jalan, trotoar & Bahu jalan, trotoar \\
\hline Shift & Tidak ada & Tidak ada & Ada \\
\hline luran & $\begin{array}{l}\text { Rp 1.000,- setiap datang } \\
\text { Rp 5.000,- tiap } 2 \text { bulan }\end{array}$ & $\begin{array}{c}\text { Rp 1.000,- } \\
\text { setiap datang }\end{array}$ & $\begin{array}{c}\text { Rp 1.000,- } \\
\text { setiap minggu }\end{array}$ \\
\hline Sistem antrian & Ada & Ada & Ada \\
\hline Kartu Anggota & $\begin{array}{c}\text { Ditandatangani } \\
\text { Ketua Paguyuban }\end{array}$ & $\begin{array}{c}\text { Ditandatangani Kanit } \\
\text { Polsek Banyumanik }\end{array}$ & $\begin{array}{c}\text { Ditandatangani Kanit } \\
\text { Polsek Banyumanik }\end{array}$ \\
\hline Pertemuan rutin & 2 bulanan & 3 bulanan & Insidentil \\
\hline $\begin{array}{l}\text { Tempat } \\
\text { pertemuan }\end{array}$ & Sekretariat & $\begin{array}{l}\text { Bergiliran rumah } \\
\text { anggota }\end{array}$ & Pangkalan \\
\hline Sarana Prasarana & $\begin{array}{l}\text { Tiang nama pangkalan, } \\
\text { kanopi, meja, bangku }\end{array}$ & $\begin{array}{c}\text { Papan nama } \\
\text { pangkalan, Papan } \\
\text { antrian, bangku }\end{array}$ & $\begin{array}{c}\text { Spanduk nama, } \\
\text { papan antrian, } \\
\text { bangku }\end{array}$ \\
\hline
\end{tabular}

Sumber: Hasil Analisis, 2015

Hasil sintesa ini diantaranya senada dengan Widayanti dan Fernandes (2012) dalam penelitian Operasional Angkutan Paratransit Sepeda Motor di Kawasan Terminal Bungurasih Surabaya, menyampaikan hasil bahwa ojek memerlukan pangkalan dan sarana komunikasi yang lebih baik bagi operator, serta peningkatan pelayanan berupa kenyamanan dan keamanan bagi pengguna sehingga dapat memenuhi kebutuhan dan harapan pengguna.

\section{Analisis Pengaturan Keberadaan Ojek Berdasarkan Pandangan Pemerintah dan Akademisi}

Ojek tidak pernah dimasukkan dalam perencanaan transportasi dan tidak diatur dalam regulasi transportasi sehingga disebut angkutan umum ilegal atau tidak resmi. Ojek muncul sebagai gap filler atau pengisi kekosongan angkutan umum sehingga dibutuhkan masyarakat yang tidak terlayani angkutan umum. Adanya Perda yang mengatur ojek di Indonesia yaitu di kota Palopo, Kabupaten Dompu dan Majene tidak diketahui oleh Kementerian Perhubungan (Kemenhub) selaku regulator penyelenggara transportasi. Hal tersebut menunjukkan kurangnya koordinasi antar pemerintah baik pusat maupun daerah. Perda yang sudah ada tersebut akan dievaluasi dan bila tidak memenuhi syarat dapat dibatalkan oleh Kementerian Dalam Negeri atas rekomendasi dari Kemenhub.

Status ojek menurut Kementerian Perhubungan adalah ilegal namun tidak bisa melarang keberadaannya karena terkait aspek sosial ekonomi, sedangkan menurut Dishubkomindo kebijakan pemerintah dapat bersifat tentatif sehingga bisa diterapkan sesuai kondisi di daerah. 
Adanya perbedaan pandangan antara regulator tersebut menunjukkan ketidaktegasan pemerintah dalam menyikapi keberadaan ojek. Tidak adanya peraturan yang jelas juga menunjukkan ketidakberpihakan Dishubkominfo dan Kemenhub terhadap keberadaan ojek sehingga tindakan penegakan hukum dan wewenang pembinaan ada pada pihak kepolisian setempat, sedangkan dalam struktur di kepolisian memang telah ada unit Bintibmas atau Digyasa untuk mengayomi dan membina komunitas-komunitas yang terbentuk di masyarakat termasuk paguyuban ojek. Paguyuban ojek tidak pernah melakukan koordinasi dengan Dishubkominfo begitu juga sebaliknya. Paguyuban ojek POAK melakukan koordinasi dengan pihak Kelurahan Jatingaleh dan Kecamatan Candisari, sedangkan paguyuban ojek Patung Diponegoro dan Bangjo berkoordinasi dengan Polsek Banyumanik.

Selanjutnya mengenai istilah 'angkutan umum ilegal' muncul berdasarkan keberadaan ojek yang tidak diatur dalam regulasi transportasi karena tidak memenuhi banyak persyaratan sebagai angkutan umum. Sedangkan dari narasumber lain mengatakan bahwa ojek merupakan angkutan paratransit, dimana menurut lles (2005) istilah "paratransit" dapat diartikan sebagai "informal", dan 'informal' itu sendiri artinya 'tidak formal' atau 'tidak resmi'. Hal ini lebih tepat untuk menggambarkan status ojek yaitu sebagai angkutan paratransit atau angkutan informal, karena istilah ilegal justru menimbulkan makna yang kontradiktif yaitu salah satunya 'melanggar hukum' yang lebih bersifat negatif ke arah tindak pidana, selain itu karena dianggap melanggar hukum seharusnya keberadaan ojek ditindak dengan tegas dan dilarang perkembangannya. Bila tidak ada pelarangan atau tindakan tegas maka hal tersebut justru melemahkan kedudukan Undang-Undang itu sendiri dimata publik.

Kartu Tanda Anggota (KTA) paguyuban ojek dibuat secara swadaya untuk menunjukkan bahwa ojek yang beroperasi adalah ojek resmi dan jelas. Sedangkan yang dibuat oleh Polsek Banyumanik bertujuan hanya untuk memantau perkembangan anggota paguyuban, dan Polsek menyatakan bahwa wewenang ijin seharusnya di dalam ranah Dishubkominfo Kota Semarang. Kementerian Perhubungan dan Dishubkominfo sebagai penyelenggara transportasi mempunyai wewenang untuk tidak memberikan ijin beroperasinya ojek sebagai angkutan umum karena keberadaan ojek tidak diatur di dalam undang-undang lalu lintas angkutan jalan dan sejenisnya. Hal ini menunjukkan bahwa pemerintah tidak berpihak terhadap keberadaan ojek.

Berdasarkan hasil wawancara Kemenhub, kepolisian sebagai aparat penegak hukum seharusnya melakukan tindakan terhadap ojek yang statusnya ilegal, namun pembinaan yang dilakukan justru menimbulkan kesan bahwa ojek 'dibekingi' oleh kepolisian dan sudah menjadi rahasia umum. Pembinaan yang dilakukan oleh unit Bintibmas atau Binmas Polsek Gajahmungkur dan Banyumanik adalah memberikan arahan agar para operator selalu berkomitmen untuk menjamin keamanan dan keselamatan baik untuk para operator itu sendiri dan terlebih khususnya bagi para pengguna atau penumpang ojek. Dalam hal ini jutru terlihat bahwa pihak kepolisian lebih berpihak terhadap keberadaan ojek daripada Dishubkominfo atau Kemenhub selaku penyelenggara sektor transportasi.

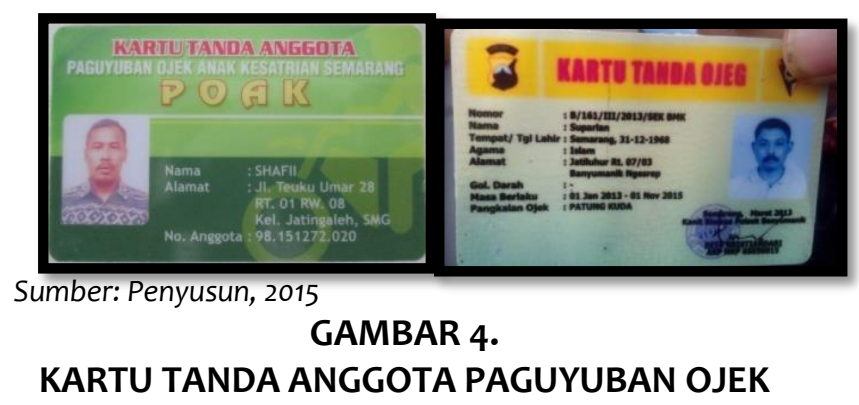


Pihak kepolisian mengharapkan ada aturan yang jelas sehingga dapat menekan atau membatasi penggunaan motor sebagai ojek. Selain itu dari segi sosial dan ekonomi keberadaan ojek sangat terkait dengan mata pencaharian untuk menafkahi anggota keluarga. Di pihak lain, Kelurahan setuju dengan dilegalkannya ojek agar ada kepastian dan payung hukum yang jelas sehingga keberadaan ojek dapat lebih tertata dengan baik, namun apapun keputusan dari pemerintah pusat, pihak kelurahan akan siap melaksanakan sesuai ketentuan yang telah ditetapkan. Demikian pula Jasa Raharja mendukung adanya pengaturan ojek yang menjamin keselamatan operator dan pengguna ojek melalui asuransi jiwa.

Namun di sisi lain, Kemenhub senada dengan Dishubkominfo tetap menyatakan bahwa jika ojek dilegalkan maka keberadaannya akan semakin berkembang, sedangkan hal tersebut justru menunjukkan kemunduran pembangunan transportasi, karena saat ini yang perlu dikembangkan adalah angkutan umum massal. Dari sisi operator ojek menyatakan tidak setuju dengan dilegalkannya ojek dengan alasan ojek menjadi terikat, tidak bebas karena rute dan tarif diatur. Sedangkan yang setuju ojek dilegalkan karena ingin kejelasan status dan perlindungan agar tetap dapat beroperasi di wilayah tersebut. Senada dengan operator ojek, pengguna ojek juga tidak setuju mengenai rute dan tarif ojek yang diatur tetapi setuju bila ojek diatur keseragamannya agar lebih tertib.

Hasil sintesa ini berbeda dengan penelitian yang sudah ada diantaranya oleh Tuan dan MateoBabiano (2013) dalam penelitian Motorcycle Taxi Service In Vietnam - Its Socioeconomic Impacts And Policy Considerations, menyatakan hasil bahwa ojek akan membantu sistem transportasi umum utama secara signifikan jika layanan inovasi dan diatur dengan baik. Oleh karena itu diperlukan suatu peraturan dalam pengelolaan armada yang fokus pada pengaturan tarif, registrasi dan perizinan, keamanan, dan emisi. Selanjutnya Loo (2007) dalam penelitian The Role Of Paratransit: Some Reflections Based On The Experience Of Residents' Coach Services in Hong Kong, menyampaikan hasil bahwa pembuat kebijakan transportasi harus memberikan perhatian lebih kepada bentuk-bentuk baru dari moda paratransit dan cara-cara mengintegrasikan moda informal tersebut ke sistem transportasi publik secara keseluruhan, baik secara spasial dan temporal.

Berdasarkan wawancara dengan para akedemisi sekaligus pengamat ahli transportasi, menyatakan bahwa pemerintah seharusnya dapat mencontoh keberhasilan pengaturan ojek di negara-negara lain karena mengingat kondisi angkutan umum yang belum baik dan optimal, sedangkan masyarakat memiliki kebutuhan mobilitas yang sangat tinggi. Oleh karena itu ada beberapa langkah-langkah kongkrit sebagai rekomendasi yang seharusnya segera dilakukan oleh pemerintah sebagai bentuk pengaturan dalam menyikapi keberadaan ojek, diantaranya:

a. Mendata titik-titik mana saja yang saat ini menjadi pangkalan ojek baik yang sudah terbentuk paguyuban atau belum.

b. Mendata tempat-tempat yang berpotensi memunculkan ojek dengan melihat bangkitan perjalanan yang ada pada suatu wilayah dan ketersediaan angkutan umum.

c. Meningkatkan ketersediaan sarana angkutan umum atau feeder dengan pelayanan tinggi dan biaya murah di titik-titik yang berpotensi memunculkan ojek.

d. Memperbaiki prasarana angkutan seperti halte dan pedestrian yang nyaman serta jalan yang diakses sehingga masyarakat mudah untuk menjangkau angkutan umum.

e. Bila sudah ada paguyuban ojek yang terbentuk maka terus melakukan pembinaan dan pendekatan untuk kemudian dapat dialihkan menjadi angkutan umum resmi yang berbadan hukum atau mengintegrasikan ojek ke sistem transportasi publik secara keseluruhan.

f. Dengan pendekatan secara bertahap, keberadaan pangkalan ojek untuk sementara dapat dialihkan pada mulut-mulut jalan lingkungan atau di depan perumahan/permukiman 
penduduk, sehingga keberadaan feeder pada koridor ranting atau jalan lokal dapat dioptimalkan.

g. Pemantauan dan pembinaan paguyuban ojek sementara dilakukan oleh pihak Kepolisian setempat yang bekerjasama pihak Kelurahan selaku perangkat daerah yang terdekat di lapangan dan berkoordinasi dengan Dishubkominfo.

h. Tidak mempermudah memberikan ijin untuk pembangunan perumahan/permukiman penduduk, namun bila memang dibutuhkan suatu permukiman maka harus mulai diterapkan konsep hunian vertikal.

Tidak dipungkiri bahwa budaya dan faktor psikologis masyarakat yang ingin semua serba mudah, cepat, instant, dan murah membuat pilihan lebih berpihak kepada ojek daripada angkutan umum massal. Sedangkan faktor keamanan, kenyamanan dan bahkan keselamatan sering diabaikan. Oleh karena itu langkah-langkah kongkrit diatas tentu saja hanya dapat dilakukan apabila ada koordinasi dan kerjasama antara stakeholder terkait mulai dari pemerintah, operator ojek yang dinaungi oleh paguyuban ojek dan masyarakat umum sebagai pengguna ojek.

\section{KESIMPULAN}

Hasil analisis menunjukkan bahwa keberadaan ojek di kota Semarang, khususnya di koridor jalan Kesatrian, Ngesrep Timur $V$ dan Karangrejo raya akan selalu dibutuhkan masyarakat sebagai pengisi kekosongan (gap filler) terhadap layanan angkutan umum yang belum optimal. Ojek akan dapat bertahan dalam waktu yang tidak terbatas selama masih ada demand dan supply antara operator dan pengguna yang saling menguntungkan. Berdasarkan karakteristik operatornya, keberadaan ojek menjadi mata pencaharian utama karena tidak mensyaratkan fisik, keahlian atau jenjang pendidikan tertentu sehingga mampu memenuhi kebutuhan ekonomi disamping kebutuhan sosial karena adanya paguyuban ojek yang dapat menampung aspirasi dan informasi antar anggotanya. Berdasarkan karakteristik kebutuhan penggunanya, ojek dapat berperan sebagai penerus (feeder) untuk meneruskan perjalanan dan sebagai pengganti (substitute) yaitu ojek digunakan dari rumah ke tujuan tanpa perlu naik angkutan umum. Ojek akan terus bertahan dan semakin diminati karena lebih cepat dan fleksibel ke berbagai tujuan dengan karakteristik door to door service. Dalam hal tarif, rute, bahkan kecepatan sepeda motor dapat disesuaikan dengan kesepakatan sehingga pengguna ojek merasa lebih tenang dan aman. Berdasarkan analisis kelembagaan terhadap historis perkembangan, peran, fungsi dan iklim kerja menunjukkan bahwa paguyuban ojek telah memiliki kinerja yang baik di bawah pantauan Kelurahan dan pembinaan Polsek setempat, sehingga keberadaan paguyuban turut membantu menciptakan lingkungan yang kondusif. Di dalam peraturan perundangan, keberadaan ojek tidak diatur karena dianggap belum memenuhi syarat sebagai angkutan umum, sehingga ojek disebut sebagai angkutan umum tidak resmi/informal/paratransit.

Hal tersebut menunjukkan bahwa pemerintah dalam hal ini adalah Kementerian Perhubungan dan Dishubkomino Kota Semarang belum berpihak terhadap keberadaan ojek karena tanpa adanya peraturan justru akan membuat ojek tidak tertib dan berkembang secara liar. Rekomendasi yang dapat diberikan adalah meninjau kembali dan bila perlu merevisi UU No. 22/2009 tentang Lalu Lintas Angkutan Jalan dan PP No. 74/2014 tentang Angkutan Jalan sehingga ojek dapat dikelompokkan sebagai angkutan orang tidak dalam trayek. Selanjutnya mendorong adanya Peraturan Daerah untuk mengatur ojek secara teknis dengan diawali langkah kongkrit seperti mendata titik-titik pangkalan ojek dan tempat-tempat yang berpotensi 
memunculkan ojek. Dibutuhkan kerjasama dan koordinasi antara Kementerian Perhubungan, Dishubkominfo, Kepolisian, Kelurahan, Paguyuban ojek dan juga partisipasi masyarakat untuk mewujudkan keberadaan ojek yang tertib dan teratur.

\section{DAFTAR PUSTAKA}

Adisasmita, Sakti Adji. 2011. Manajemen Transportasi Darat. Yogyakata: Graha Ilmu.

Bahar, Taslim et al. 2011. "Potensi Penggunaan Angkutan Informal di Kota Bandung". Jurnal Transportasi, Vol. 11, No. 3, Desember, hal. 209-218.

Edi, Agus Sarwo. 2004. "Karakteristik Pengoperasian Angkutan Ojek Sebagai Sarana Angkutan Di Kota Gubug”. Tugas Akhir tidak diterbitkan, Program Studi Perencanaan Wilayah dan Kota, Fakultas Teknik Universitas Diponegoro, Semarang.

Era, Andi M. 2014. "Urgensi Pengaturan Ojek Di Daerah Sebagai Angkutan Umum Dalam Undang-Undang". Artikel Ilmiah tidak diterbitkan, Jurusan Ilmu Hukum, Fakultas Hukum Universitas Brawijaya, Malang.

Fasakin, J.O. 2001. "Some Factors Affecting Daily Profits Of Commercial Motorcycles in Akure Nigeria". Transport Policy 8, pp. 63-69.

Handayani, Dewi et al. 2009. "Karakteristik Alat Transportasi Informal Ojek Sepeda Motor di Perkotaan (Studi Kasus Kota Surakarta)". Makalah disampaikan pada Seminar Nasional Pascasarjana IX - ITS, Surabaya 12 Agustus 2009.

lles, Richard. 2005. Public Transport in Developing Countries. Amsterdam: Elsevier.

Joewono and Kubota. 2005. "The Characteristics Of Paratransit And Non-Motorized Transport In Bandung, Indonesia”. Journal of the Eastern Asia Society for Transportation Studies, Vol. 6, pp. $262-277$.

Loo, Becky P.Y. 2007. "The Role Of Paratransit: Some Reflections Based On The Experience Of Residents' Coach Services in Hong Kong”. Transportation 34, pp. 471-486.

Miro, Fidel . 2005. Perencanaan Transportasi untuk Mahasiswa, Perencana, dan Pratisi. Jakarta: Penerbit Erlangga.

Morlok, Edward K. 1988. Pengantar Teknik dan Perencanaan Transportasi. Terjemahan Johan Kelanaputra Hainim. Jakarta : Penerbit Erlangga.

Peraturan Pemerintah Republik Indonesia Nomor 74 Tahun 2014 Tentang Angkutan Jalan. Direktorat Jenderal Perhubungan Darat Kementerian Perhubungan Jakarta, 2014.

Rencana Tata Ruang Wilayah Kota Semarang 2011-2031. Badan Perencana Pembangunan Daerah Kota Semarang, 2011.

Saputra, Rendy. “Ojek". Available at: http://m.kompasiana.com/post/read/430686/1/ojek.html. Diakses pada tanggal 30 September 2014.

Syahyuti. 2010. Pedoman Singkat Untuk Menilai Sebuah Organisasi. Available at: http://kelembagaandas.wordpress.com/analisis-kelembagaan/syahyuti-2. Diakses pada tanggal 21 Oktober 2014.

Tamin, Ofyar Z . 2008. Perencanaan, Permodelan dan Rekayasa Transportasi. Bandung: Penerbit ITB.

Tuan, Vu Anh and Mateo-Babiano. 2013. "Motorcycle Taxi Service In Vietnam - Its Socioeconomic Impacts And Policy Considerations". Proceedings of the Eastern Asia Society for Transportation Studies. Vol.9.

Undang-Undang Republik Indonesia Nomor 22 Tahun 2009 tentang Lalu Lintas dan Angkutan Jalan. Direktorat Jenderal Perhubungan Darat Kementerian Perhubungan Jakarta, 2009.

Warpani, Suwajoko. 1990. Merencanakan Sistem Pengangkutan. Bandung: Penerbit ITB. 